\author{
Katarzyna Leśkiewicz \\ Uniwersytet im. A. Mickiewicza w Poznaniu \\ kles@amu.edu.pl
}

\title{
Z problematyki stosowania przepisów regulujących „dyspozycję wkładem na wypadek śmierci”
}

\section{From the Issues of Application of Provisions of the Instruction Concerning the Disposal of a Deposit in the Event of Death}

\begin{abstract}
The subject of the paper is the issue of application of the provisions governing the instruction concerning the disposal of a deposit in the event of death. The institution above mentioned is used in banking practice and cooperative banking. The legislator decided that the amounts paid on the title of the instruction concerning the disposal of the deposit in the event of death, in accordance with Article $56 \mathrm{sec} .1$ of the Banking Act and Article 14 sec. 1 p. 2 of the Act on the Cooperative Cash Saving Bank, shall not be included in the account holder's estate. The aim of the paper is to answer the question - how the amounts paid on the title of the instruction concerning the disposal of the deposit in the event of death should be treated given the provisions of Article 993 and 996 of the Civil Code. In her conclusions the author states that the amounts paid on the title of the instruction concerning the disposal of the deposit in the event of death should be treated in the same way as gratuitous donations, regulated by Article 993 and 996 of the Code.
\end{abstract}

Keywords: disposal of the deposit in the event of death, banking act, legitim preserve Słowa kluczowe: dyspozycja wkładem, zachowek, prawo bankowe

\section{Wprowadzenie}

Przedmiotem rozważań jest problematyka stosowania przepisów regulujących tzw. dyspozycję wkładem na wypadek śmierci. Instytucja ta wykorzystywana jest w praktyce obok innych szczególnych tzw. poza-testamentowych postaci rozrządzeń, 
jak np. dyspozycja uczestnika funduszu inwestycyjnego otwartego ${ }^{1}$ czy dyspozycja środkami zgromadzonymi $\mathrm{w}$ funduszu emerytalnym ${ }^{2}$. W myśl art. 56 ust. 1 ustawy Prawo bankowe 3 , posiadacz rachunku oszczędnościowego, rachunku oszczędnościowo-rozliczeniowego lub rachunku terminowej lokaty oszczędnościowej może polecić pisemnie bankowi dokonanie - po swojej śmierci - wypłaty z rachunku wskazanym przez siebie osobom: małżonkowi, wstępnym, zstępnym lub rodzeństwu określonej kwoty pieniężnej (dyspozycja wkładem na wypadek śmierci). Przy czym nie może być to kwota wyższa, niż dwudziestokrotne przeciętne miesięczne wynagrodzenie w sektorze przedsiębiorstw bez wypłat nagród z zysku, ogłaszane przez Prezesa Głównego Urzędu Statystycznego za ostatni miesiąc przed śmiercią posiadacza rachunku (art. 56 ust. 2 prawa bankowego) ${ }^{4}$. Jednocześnie, ustawodawca postanowil, iż „kwota wypłacona” zgodnie $\mathrm{z}$ art. 56 ust. 1 prawa bankowego nie wchodzi do spadku po posiadaczu rachunku.

Natomiast zgodnie z ustawą o spółdzielczych kasach oszczędnościowo-kredytowych ${ }^{5}$, kasa jest obowiązana wypłacić po śmierci członka kasy z jego wkładu członkowskiego i oszczędności: kwotę nieprzekraczającą ogółem sumy przeciętnego miesięcznego wynagrodzenia w gospodarce narodowej, ogłaszanej przez Prezesa Głównego Urzędu Statystycznego, w okresie 5 lat kalendarzowych poprzedzających wypłatę - jeżeli członek kasy pisemnie wskazał kasie osoby, na których rzecz wypłata ma nastąpić; osobami wskazanymi przez członka kasy mogą być: jego małżonek, zstępni, rodzice, dziadkowie i rodzeństwo (art. 14 ust. 1 pkt 2 ustawy o SKOK). Jednocześnie sumy objęte postanowieniem art. 14 ust. 1 pkt 2 ustawy o SKOK nie należą do spadku po członku kasy. Z kolei w przypadku powzięcia przez kasę informacji o śmierci członka kasy, który dokonał wskazania wymienionych wyżej osób, kasa jest obowiązana niezwłocznie zawiadomić wskazane przez członka kasy osoby o możliwości wypłaty określonej kwoty (art. 14 ust. 2b ustawy o SKOK).

Prawna problematyka dyspozycji wkładem na wypadek śmierci była przedmiotem rozważań $\mathrm{w}$ literaturze prawniczej ${ }^{6}$. $\mathrm{Z}$ teoretycznoprawnego punktu widzenia,

1 Art. 111 ust. 1 pkt 2 ustawy z dnia 27 maja 2004 r. o funduszach inwestycyjnych i zarządzaniu alternatywnymi funduszami inwestycyjnymi (tekst jedn. Dz.U. z 2016 r. poz. 1896).

2 Art. 82 ust. 1 ustawy o organizacji i funkcjonowaniu funduszy emerytalnych (tekst jedn. Dz.U. z 2017 r. poz. 870).

3 Ustawa z dnia 29 sierpnia 1997 r. Prawo bankowe (tekst jedn. Dz.U. z 2016 r. poz. 1988 ze zm.), dalej zwana „prawem bankowym”.

$4 \quad$ Według danych Głównego Urzędu Statystycznego kwota ta w maju 2017 r. wyniosła 87.780,80 zł (Dz.Urz. GUS z 2017 r., poz. 27).

5 Ustawa z dnia 5 listopada 2009 r. o spółdzielczych kasach oszczędnościowo-kredytowych (tekst jedn. Dz.U. z 2016 r. poz. 1810 ze zm.), dalej zwana „ustawą o SKOK”, a kasy oszczędnościowo-kredytowe zwane są dalej „SKOK”.

6 Np. F. Rakiewicz, Charakter prawny dyspozycji wkładem na wypadek śmierci (art. 56 ustawy PrBank) - cz. II, „Monitor Prawniczy” 2005, s. 20, Legalis; W. Pyzioł, Pozatestamentowe formy dysponowania wkładem oszczędnościowym na wypadek śmierci, (w:) Księga Pamiątkowa dla 
Z problematyki stosowania przepisów regulujących „dyspozycję wkładem...

instytucja dyspozycji na wypadek śmierci porównywana jest w piśmiennictwie do „rozrządzenia majątkowego na wypadek śmierci”, podobnego do testamentu z uwagi na wyjątek od zasady przewidzianej w art. 941 kodeksu cywilnego ${ }^{7}$. Dlatego niektórzy autorzy uznają za zasadne „stosowanie do omawianej dyspozycji wkładcy, w drodze ostrożnej analogii, przepisów kodeksu cywilnego o testamencie, w tym zwłaszcza reguły (art. 947 kodeksu cywilnego)"8.

W zakresie charakteru prawnego dyspozycji wkładem na wypadek śmierci wskazuje się, iż jest ona „jednostronną czynnością prawną mortis causa”, co przesądza również o konsekwencjach prawnych, m.in. takich jak ta, że bank nie oświadcza swojej woli, a jedynie przyjmuje dyspozycję o treści określonej przez posiadacza rachunku w ramach prawem przewidzianych i jest adresatem oświadczenia woli posiadacza rachunku, a także że dokonanie zastrzeżenia nie ma wpływu na sposób i swobodę rozporządzania środkami na rachunku przez posiadacza rachunku, dotyczy to też swobody w dysponowaniu stosunkiem prawnym jako takim ${ }^{9}$. Inni autorzy także traktują tę instytucję jako „uprawnienie posiadacza rachunku polegające na poleceniu bankowi dokonania wypłaty środków zgromadzonych na rachunku po swojej śmierci wskazanej osobie"10. Konstrukcja dyspozycji wkładem na wypadek śmierci uznawana jest za wyjątek od ogólnej zasady, zgodnie z którą można rozrządzić majątkiem na wypadek śmierci jedynie w drodze testamentu ${ }^{11}$.

Natomiast, gdy chodzi o regulację art. 14 ust. 1 pkt 2 ustawy o SKOK, wskazać trzeba, że wkład członkowski pochodzi ze stosunku członkostwa, a oszczędności członka złożone w kasie opierają się na umowie rachunku ${ }^{12}$. Kasa dokonuje wypłaty z oszczędności złożonych na imiennym rachunku członka kasy i wkładu członkowskiego, zaś bank ze środków zgromadzonych na rachunkach posiadacza.

W świetle art. $922 \S 2$ kodeksu cywilnego, zgodnie z którym nie należą do spadku prawa i obowiązki zmarłego ściśle związane z jego osobą, jak również prawa, które z chwilą jego śmierci przechodzą na oznaczone osoby niezależnie od tego, czy

uczczenia pracy naukowej Profesora Kazimierza Kruczalaka, t. V, 1999, s. 357-366; R. Tollik, (w:) W. Góralczyk (red.), Prawo bankowe. Komentarz, Warszawa 1999, s. 159; Z. Ofiarski, Prawo bankowe. Komentarz, Warszawa 2013, komentarz do art. 56; D. Rogoń, (w:) F. Zoll (red.), Prawo bankowe. Komentarz, Lex 2005, komentarz do art. 56; por. analogicznie, B. Smykla, Prawo bankowe. Komentarz, Warszawa 2011, komentarz do art. 56.

7 Ustawa z dnia 23 kwietnia 1964 r. - Kodeks cywilny (tekst jedn. Dz.U. z 2017 r. poz. 459 ze zm.), dalej zwana „kodeksem cywilnym”.

$8 \quad$ Z. Ofiarski, Prawo bankowe..., op. cit., komentarz do art. 56.

9 D. Rogoń, Prawo bankowe..., op. cit., komentarz do art. 56; por. analogicznie, B. Smykla, Prawo bankowe..., op. cit., komentarz do art. 56.

10 B. Bieniek, Komentarz do przepisów 51-56, 104 Prawa bankowego, (w:) J. Ignaczewski (red.), Małżeńskie prawo majątkowe. Komentarz, Warszawa 2017.

11 H. Gronkiewicz-Waltz (red.), Prawo bankowe. Komentarz, Warszawa 2013.

12 A. Herbet, S. Pawłowski, P. Zakrzewski, Spółdzielcze kasy oszczędnościowo-kredytowe. Komentarz, Warszawa 2014. 
są one spadkobiercami, kwota objęta wspomnianym „zapisem” z chwilą śmierci posiadacza rachunku winna przejść na osoby, które wskazane zostały w dyspozycji. Naturalnie, w przypadku braku środków na rachunku bank albo odpowiednio - kasa nie zrealizuje dyspozycji wkładem na wypadek śmierci, a dyspozycja pozostanie niewykonalna.

Przywołane powyżej regulacje pozwalają w praktyce na wypłatę rachunków bankowych, lokat oszczędnościowych i kont oszczędnościowo-rozliczeniowych oraz wyjątkowo $\mathrm{z}$ wkładu w przypadku ustawy o SKOK - kwot w wysokości ustawowo określonej jako niewchodzących do spadku po zmarłym posiadaczu, jedynie osobom fizycznym nieprowadzącym działalności gospodarczej. Wspomniane regulacje inspirują do zadawania pytań o skutki prawne, jakie za sobą pociągają, co naturalnie wymaga odniesienia do stanowisk literatury i orzecznictwa sądowego. Celem rozważań jest odpowiedź na pytanie, jak należy traktować kwoty otrzymane w związku z dyspozycjami wkładem na wypadek śmierci na podstawie art. 56 ust. 1 prawa bankowego oraz art. 14 ust. 1 pkt 2 ustawy o SKOK w świetle przepisów kodeksu cywilnego dotyczących zachowku (art. 993 i 996 kodeksu cywilnego).

\section{Prawna regulacja dyspozycji wkładem na wypadek śmierci}

Przy porównaniu przepisów art. 56 ust. 5 prawa bankowego i art. 14 ust. 2 ustawy o SKOK widać różnicę. Biorąc pod uwagę literalne brzmienie przepisu art. 56 ust. 5 prawa bankowego, trzeba zauważyć, iż mowa jest w tym przepisie o „kwotach wypłaconych", które nie wchodzą do spadku po zmarłym. Stosownie do art. 14 ust. 2 ustawy o SKOK, „sumy określone w art. 14 ust. 1 nie należą do spadku po członku kasy”. Nie jest jednocześnie jasne, w jakim celu ustawodawca wyróżnił „kwoty wypłacone" w prawie bankowym, a nie użył takiego określenia w przypadku rozwiązania zawartego w ustawie o SKOK i czy należy nadawać temu rozróżnieniu jakieś znaczenie praktyczne. Sens literalnego brzmienia art. 56 ust. 5 prawa bankowego nakazuje przyjmować, iż jedynie „kwoty wypłacone” nie wchodzą do spadku, natomiast a contrario - kwoty niewypłacone są do niego zaliczone. Pojawia się pytanie, czy taki kierunek interpretacji prowadzi do konieczności uwzględniania tych „niewypłaconych" kwot przez spadkobierców z grupy osób najbliższych ustawowo zwolnionych $\mathrm{z}$ podatku od spadków przy zgłoszeniach nabycia w celu skorzystania ze zwolnienia ${ }^{13}$, mimo iż nie zawsze to te osoby będą uprawnionymi z tytułu dyspozycji wkładem na wypadek śmierci (np. w przypadku pozostawienia testamentu przez spadkodawcę). Różnica w traktowaniu kwot objętych dyspozycjami w art. 56 ust. 5 prawa bankowego i art. 14 ust. 2 ustawy o SKOK wydaje się nieuzasadniona i w ra-

13 Art. 4a ustawy z dnia 22 lipca 1983 r. o podatku od spadków i darowizn (tekst jedn. Dz.U. z 2017 r. poz. 833 ze zm.), dalej zwana „ustawą o podatku od spadków”. Kwoty wypłacone beneficjentowi podlegają podatkowi od spadków i darowizn, por. B. Bieniek, Komentarz do przepisów..., op. cit. 
mach wniosków de lege ferenda należałoby postulować ujednolicenie podejścia ustawodawcy do dyspozycji wkładem na wypadek śmierci w taki sposób, by kwoty objęte zapisem, tak w bankach, jak i SKOK-ach, podlegały takim samym zasadom, niezależnie od tego, czy zostały wypłacone czy nie, tj. by z mocy ustanowienia dyspozycji nie wchodziły do spadku.

W zakresie skutków prawnych dyspozycji na wypadek śmierci, w sferze dochodzenia roszczeń o zachowek, należy ustalić, w jaki sposób następuje wskazanie podstaw do obliczenia zachowku. I tak, w pierwszej kolejności należy najpierw określić udział spadkowy stanowiący podstawę do obliczenia zachowku, a następnie ustalić tzw. substrat zachowku, co wymaga przede wszystkim określenia czystej wartości spadku, czyli różnicy pomiędzy stanem czynnym spadku (wartością wszystkich praw należących do spadku, według ich stanu z chwili otwarcia spadku) a stanem biernym spadku (sumą długów spadkowych, z pominięciem jednak długów wynikających $\mathrm{z}$ zapisów i poleceń) ${ }^{14}$. W kolejnych krokach do czystej wartości spadku dolicza się, w celu ustalenia substratu zachowku, wartość darowizn dokonanych przez spadkodawcę, bez względu na to, czy były one uczynione na rzecz spadkobierców uprawnionych do zachowku, czy też innych osób. Z kolei wartość przedmiotu darowizny na potrzeby doliczenia oblicza się według stanu z chwili jej dokonania, a według cen z chwili ustalenia zachowku. W praktyce zasadne jest zatem pytanie, jak na tle art. 993 i 996 kodeksu cywilnego traktować dyspozycje na wypadek śmierci i przysporzenia otrzymane w ich ramach? W przepisach nie znajdujemy bowiem odpowiedzi wprost, czy beneficjent dyspozycji wkładem na wypadek śmierci posiada analogiczny status prawny, jak obdarowany czy zapisobierca windykacyjny.

Zgodnie z art. 993 kodeksu cywilnego, przy obliczaniu zachowku nie uwzględnia się zapisów zwykłych i poleceń, natomiast dolicza się do spadku, stosownie do przepisów poniższych, darowizny ${ }^{15}$ oraz zapisy windykacyjne dokonane przez spadkodawcę. Chodzi zwłaszcza o to, czy dyspozycje wkładem na wypadek śmierci należy tak jak darowizny doliczać do spadku przy obliczaniu zachowku (art. 993 kodeksu cywilnego). Natomiast w myśl art. 996 kodeksu cywilnego, zapis windykacyjny oraz darowiznę dokonane przez spadkodawcę na rzecz uprawnionego do zachowku zalicza się na należny mu zachowek. Jeżeli uprawnionym do zachowku jest dalszy zstępny spadkodawcy, zalicza się na należny mu zachowek także zapis windykacyjny oraz darowiznę dokonane przez spadkodawcę na rzecz jego wstępnego. Stąd kwe-

14 Art. 991-1011 kodeksu cywilnego. Darowizny zwiększają jedynie czynną stronę substratu zachowku, a w razie istnienia długów ich doliczenie nie musi oznaczać, że zachowek wystąpi; zob. wyrok Sądu Najwyższego z dnia 30 stycznia 2008 r., III CSK 255/07, OSN 2009, nr 3, poz. 47.

15 Jednakże, gdy spadkodawca dokonał darowizny wyczerpującej cały spadek, uprawniony do zachowku może dochodzić od obdarowanego roszczenia o zachowek w granicach określonych w art. 1000 kodeksu cywilnego. Odpowiedzialność na podstawie art. 1000 kodeksu cywilnego ogranicza się do wartości wzbogacenia będącego skutkiem darowizny, wyrok Sądu Apelacyjnego w Warszawie z dnia 10 lipca 2014 r., I ACa 113/14, Lex nr 1527263. 
stią wątpliwą jest to, czy kwoty dyspozycji wkładem na wypadek śmierci zaliczane winny być na poczet należnego zachowku (art. 996 kodeksu cywilnego) i dalej - analogicznie czy w odniesieniu do prawa do zachowku dalszego zstępnego spadkodawcy należy zaliczyć na należny mu zachowek kwoty z dyspozycji wkładem poczynionej na rzecz jego wstępnego (art. 996 kodeksu cywilnego).

\section{Możliwość traktowania zapisów na wypadek śmierci jak darowizny}

W literaturze wskazuje się (pogląd D. Rogoń), że przy obliczaniu i dochodzeniu zachowku uwzględnia się kwoty zapisu bankowego, zaś sporne jest to, czy należy je traktować analogicznie do dokonanych za życia darowizn czy też zapisów ${ }^{16}$. Natomiast P. Księżak za większością doktryny zdecydowanie uznaje, że kwoty wynikające z bankowej dyspozycji na wypadek śmierci uwzględnia się przy obliczaniu i dochodzeniu zachowku na takich samych zasadach jak darowizny w kontekście art. 993 kodeksu cywilnego ${ }^{17}$. Zatem w świetle tych stanowisk, doliczeniu do spadku podlegać winna wartość kwot wypłaconych z rachunku bankowego spadkodawcy na podstawie art. 56 prawa bankowego. Za takim kierunkiem rozumowania przemawia argument podawany w piśmiennictwie, wedle którego wspomniane kwoty nie wchodzą w skład spadku, jednakże osoba uposażona uzyskuje przysporzenie zazwyczaj nieodpłatnie $^{18}$. Skutki takiego kierunku interpretacji prowadzą do wniosku m.in., że zgodnie z przepisem art. 1000 kodeksu cywilnego, jeżeli uprawniony nie mógłby otrzymać od spadkobiercy należnego mu zachowku, mógłby on żądać od osoby, która otrzymała od spadkodawcy darowiznę doliczoną do spadku (tudzież kwotę wypłaconą na podstawie dyspozycji na wypadek śmierci), sumy pieniężnej potrzebnej do uzupełnienia zachowku, a beneficjent dyspozycji na wypadek śmierci traktowanej jako darowizna byłby obowiązany do zapłaty powyższej sumy tylko w granicach wzbogacenia będącego skutkiem takiej „darowizny”, a jeśli sam byłby uprawniony do zachowku, ponosiłby odpowiedzialność względem innych uprawnionych do zachowku tylko do wysokości nadwyżki przekraczającej jego własny zachowek.

P.M. Głuchowski wskazuje natomiast, że dyspozycja na wypadek śmierci nie może zostać zakwalifikowana jako darowizna w rozumieniu przepisów art. 993, 996, 1000 i 1039 kc. i postuluje za W. Pyziołem, uregulowanie tej kwestii expressis verbis $\mathrm{w}$ ustawie, aby nie pojawiały się na tym tle wątpliwości interpretacyjne ${ }^{19}$.

16 D. Rogoń, Prawo bankowe..., op. cit., komentarz do art. 56 i powołana tam literatura; por. analogicznie, B. Smykla, Prawo bankowe..., op. cit.

17 P. Księżak, Komentarz do art. 993 kc., (w:) K. Osajda (red.), Kodeks cywilny. Komentarz, Warszawa 2017.

18 M. Pazdan, (w:) K. Pietrzykowski (red.), KC. Komentarz, t. 2, Warszawa 2013, s. 910.

19 P.M. Głuchowski, Umowa rachunku w spółdzielczej kasie oszczędnościowo-kredytowej, Oficyna 2009, Lex. 
Z problematyki stosowania przepisów regulujących „dyspozycję wkładem...

Gdy chodzi o orzecznictwo, to w szczególności zdaniem Sądu Apelacyjnego w Szczecinie w wyroku z dnia 30 listopada 2016 r., przewidziany w art. 993 kodeksu cywilnego sposób ustalania wysokości zachowku, a więc wymóg doliczenia darowizn oraz zapisów windykacyjnych dokonanych przez spadkodawcę uniemożliwia mu proste obejście przepisów o ochronie osób najbliższych przed dyspozycjami na wypadek śmierci, a dokonując analizy gramatyczno-językowej art. 993 kodeksu cywilnego uznać należy, że intencją ustawodawcy, co do ukształtowania zamkniętego katalogu przypadków doliczeń, było to, żeby istniała możliwość doliczenia do masy spadkowej przedmiotów, środków pieniężnych, które w chwili otwarcia spadku nie należały już do majątku zmarłego, ponieważ zostały przeniesione do majątku osoby trzeciej w drodze darowizny lub zapisu windykacyjnego ${ }^{20}$. Z kolei w wyroku Sądu Apelacyjnego we Wrocławiu z dnia 9 listopada 2016 r. wskazano, iż interpretacja pojęcia darowizny na gruncie przepisów o zachowku musi być powiązana z celem, któremu służy instytucja doliczania darowizny, dlatego więc obejmuje nie tylko umowę $\mathrm{z}$ art. 888 kodeksu cywilnego, ale również takie nieodpłatne czynności spadkodawcy, które następują z majątku spadkodawcy, powodują zmniejszenie spadku i z punktu widzenia osób uprawnionych mogą prowadzić do takiego samego ich pokrzywdzenia jak darowizny ${ }^{21}$. Jednakże nie wszystkie „przysporzenia mogą być uznane za „darowiznę” w świetle art. 993 kodeksu cywilnego. Przykładowo, Sąd Najwyższy wskazał, iż umowa o nieodpłatne przekazanie gospodarstwa rolnego następcy, zawarta w ramach przepisów ustawy z dnia 14 grudnia 1982 r. o ubezpieczeniu społecznym rolników indywidualnych i członków ich rodzin ${ }^{22}$, nie należy do kategorii darowizn w rozumieniu przepisu art. 993 kodeksu cywilnego ${ }^{23}$.

W kontekście regulacji art. 996 kodeksu cywilnego, doktryna prezentuje stanowisko, wedle którego na zachowek uprawnionemu dolicza się darowizny, które zostały doliczone do substratu zachowku przy obliczaniu zachowku tego uprawnionego (art. 993 i n. kodeksu cywilnego). Chodzi tu także o przysporzenia, które zostały dokonane na tych samych zasadach co darowizny doliczone do spadku, a więc również środki z dyspozycji wkładem na wypadek śmierci ${ }^{24}$. Według niektórych autorów, uprawniony jest zobowiązany do zaliczania na poczet zachowku wszelkich da-

20 Wyrok Sądu Apelacyjnego w Szczecinie z dnia 30 listopada 2016 r., I ACa 562/16, Lex nr 2201314.

21 Wyrok Sądu Apelacyjnego we Wrocławiu z dnia 9 listopada 2016 r., I ACa 914/16, Legalis; analogicznie: Wyrok Sądu Apelacyjnego w Warszawie z dnia 26 listopada 2014 r., VI ACa 99/14, Legalis.

22 Tekst jedn. Dz.U. z 1989 r. Nr 24, poz. 133 ze zm.

23 Postanowienie Sądu Najwyższego z dnia 20 maja 2016 r., V CSK 692/15, Lex nr 2054493; choć według A. Lichorowicza należałoby uwzględnić przy ustalaniu prawa do zachowku także wartość gospodarstwa rolnego przekazanego nieodpłatnie następcy, zob. bliżej A. Lichorowicz, Dziedziczenie gospodarstwa rolnego w świetle art. 90 ustawy o ubezpieczeniu rolników, „Państwo i Prawo" 1992, z. 4, s. 5.

24 P. Księżak, Kodeks cywilny..., op. cit., komentarz do art. 996 i powołana tam literatura. 
rowizn, nawet takich, które nie podlegały uwzględnieniu przy określaniu substratu zachowku ${ }^{25}$.

Wspomniane wyżej kwestie są przedmiotem rozstrzygnięć także w innych orzeczeniach niż wyżej powołane. W wyroku z dnia 6 listopada 2013 r. Sąd Apelacyjny w Warszawie przyjął, iż na poczet roszczenia o zachowek należy doliczyć wartość darowizny (choć jedynie w połowie z uwagi na to, iż dokonali jej małżonkowie), a co istotne również „kwotę zapisu bankowego”, ponieważ jednak w rozpoznawanej sprawie suma tych kwot przewyższyła należny zachowek, powództwo podlegało oddaleniu $^{26}$. Również Sąd Okręgowy w Lublinie w orzeczeniu z dnia 8 października 2013 r. uznał, że kwota wypłacona pozwanemu na podstawie dyspozycji na wypadek śmierci powinna zostać doliczona do spadku tak jak darowizna. Sąd wyraził pogląd, iż „jest to rozrządzenie nieodpłatne, mimo że uregulowane w sposób szczególny w prawie bankowym. W zakresie celu przysporzenia instytucja ta nie różni się w sposób istotny od darowizny i nie realizuje innych celów, jak np. umowa przekazania gospodarstwa rolnego. Wprawdzie w doktrynie wyrażane są rozbieżne poglądy na temat tego, czy taka dyspozycja powinna być traktowana jak darowizna, jednakże sąd okręgowy, mając na względzie charakter tej dyspozycji, skłania się do poglądu wyrażonego przez Elżbietę Skowrońską-Bocian ${ }^{27}$, iż sumy wypłacone na tej podstawie należy doliczyć do spadku"28.

Gdy chodzi natomiast o kwestię doliczania do podstawy obliczania zachowku, kwoty wypłacone tytułem dyspozycji na wypadek śmierci Sąd Apelacyjny w Poznaniu $\mathrm{w}$ wyroku z dnia 6 marca 2013 r., pominął wskazując, iż nie wchodzą one do spadku ${ }^{29}$. Również w orzeczeniu Sądu Okręgowego w Elblągu wskazano, iż: (...) „nie ulega wątpliwości, że poza zakresem badania i orzekania pozostaje też instytucja tzw. zapisu bankowego, czyli dyspozycji wkładem pieniężnym, posiadanym w banku, na wypadek śmierci posiadacza rachunku bankowego. Twierdzenie to jest tym bardziej zasadne, gdy uwzględni się, że wypłacona beneficjentowi przez bank kwota nie wchodzi do spadku po posiadaczu rachunku, jest odrębnym od nabycia spadku na podstawie ustawy czy testamentu trybem rozdziału majątku pozostałego po osobie zmarłej. (....) Beneficjent dyspozycji (...) nie będzie więc zobowiązany do ja-

25 B. Kordasiewicz, (w:) B. Kordasiewicz (red.), System Prawa Prywatnego. Tom 10, Warszawa 2015, Legalis.

26 Wyrok Sądu Apelacyjnego w Warszawie z dnia 6 listopada 2013 r., I ACa 249/13, www.orzeczenia. ms.gov.pl.

27 E. Skowrońska-Bocian, Komentarz do Kodeksu cywilnego. Część czwarta. Spadki, Warszawa 1995, s. 147-148.

28 Wyrok Sądu Okręgowego w Lublinie z dnia 8 października 2013 r., II Ca 514/13, II Cz 698/13, www.orzeczenia.ms.gov.pl.

29 Wyrok Sądu Apelacyjnego w Poznaniu z dnia 6 marca 2013 r., I ACa 85/13, www.orzeczenia.ms. gov.pl. 
Z problematyki stosowania przepisów regulujących „dyspozycję wkładem...

kichkolwiek świadczeń wobec spadkobierców posiadacza rachunku i to bez względu na to, że sam należy do ich grona" ${ }^{30}$.

W ramach darowizn dokonanych przez spadkodawcę Sąd Okręgowy w Siedlcach potraktował kwotę wypłaconą w związku z likwidacją rachunku lokaty terminowej i dyspozycji na wypadek śmierci na podstawie art. 56 ust. 1 prawa bankowego jak darowiznę. Sąd stwierdził, iż ponieważ sumy objęte i wypłacone tytułem dyspozycji na wypadek śmierci nie wchodzą do spadku, a uprawniony do nich uzyskuje przysporzenie z reguły nieodpłatnie, „uzasadnia to doliczenie wypłaconej sumy do wartości spadku stanowiącej podstawę obliczenia należnego uprawnionemu zachowku jako darowizny" 31 .

\section{Podsumowanie}

Podsumowując niniejsze rozważania wypada stwierdzić, iż więcej uwagi w literaturze i orzecznictwie poświęca się instytucji dyspozycji na wypadek śmierci uregulowanej w prawie bankowym, niż ustawie o SKOK. Dyspozycje wkładem na wypadek śmierci uregulowane tak w art. 56 ust. 1 prawa bankowego, jak i art. 14 ust. 1 pkt. 2 ustawy o SKOK w zakresie wypłaconych przez osoby uprawnione kwot, niewątpliwie są przysporzeniami, ze swej „natury” nieodpłatnymi, dlatego według stanowisk prezentowanych w literaturze i orzecznictwie wykazują podobieństwo do umowy darowizny. Z tych względów należy opowiedzieć się za traktowaniem ich jak darowizn (choć oczywiście typowymi darowiznami nie są) przy rozliczeniach, o jakich mowa w art. 993 i 996 kodeksu cywilnego, z uwzględnieniem konsekwencji, jakie wynikają również z innych przepisów kodeksu cywilnego dotyczących zachowku (np. art. 1000). Zasadny jest postulat, $z$ uwagi na podnoszone $w$ literaturze wątpliwości, uregulowania przez ustawodawcę skutków prawnych dyspozycji wkładem na wypadek śmierci w sposób wyraźny.

\section{BIBLIOGRAFIA}

Bieniek B., Komentarz do przepisów 51-56, 104 Prawa bankowego, (w:) J. Ignaczewski (red.), Małżeńskie prawo majątkowe. Komentarz, Warszawa 2017.

Głuchowski P.M., Umowa rachunku w spółdzielczej kasie oszczędnościowo-kredytowej, Oficyna 2009.

Gronkiewicz-Waltz H. (red.), Prawo bankowe. Komentarz, Warszawa 2013.

30 Postanowienie Sądu Okręgowego w Elblągu z dnia 11 czerwca 2014 r., I ACa 145/14, www.orzeczenia.ms.gov.pl; por. także Wyrok Sądu Apelacyjnego w Białymstoku z dnia 14 maja 2014 r., I ACa 78/14, www.orzeczenia.ms.gov.pl.

31 Wyrok Sądu Okręgowego w Siedlcach z dnia 25 września 2014 r., I C 614/11, www.orzeczenia.ms. gov.pl. 
Herbet A., Pawłowski S., Zakrzewski P., Spółdzielcze kasy oszczędnościowo-kredytowe. Komentarz, Warszawa 2014.

Kordasiewicz B., (w:) B. Kordasiewicz (red.), System Prawa Prywatnego. Tom 10, Warszawa 2015.

Księżak P., (w:) K. Osajda (red.), Kodeks cywilny. Komentarz, Warszawa 2017.

Lichorowicz A., Dziedziczenie gospodarstwa rolnego w świetle art. 90 ustawy o ubezpieczeniu rolników, „Państwo i Prawo” 1992, z. 4.

Ofiarski Z., Prawo bankowe. Komentarz, Warszawa 2013.

Pazdan M., (w:) K. Pietrzykowski (red.), KC. Komentarz, t. 2, Warszawa 2013.

Pyzioł W., Pozatestamentowe formy dysponowania wkładem oszczędnościowym na wypadek śmierci, (w:) Księga Pamiątkowa dla uczczenia pracy naukowej Profesora Kazimierza Kruczalaka, t. V, 1999.

Rakiewicz F., Charakter prawny dyspozycji wkładem na wypadek śmierci (art. 56 ustawy - PrBank) cz. II, „Monitor Prawniczy” 2005.

Rogoń D., (w:) F. Zoll (red.), Prawo bankowe. Komentarz, Warszawa 2005.

Smykla B., Prawo bankowe. Komentarz, Warszawa 2011.

Tollik R., (w:) W. Góralczyk (red.), Prawo bankowe. Komentarz, Warszawa 1999. 